\title{
The Apocryphal Geography of the Virgin Mary in Hagiographic Collections: Dissemination and Liturgy
}

\author{
Andrea-Bianka Znorovszky \\ Joint Excellence in Science and Humanities Fellow, Austrian Academy of \\ Sciences, Universität Salzburg, Institut für Realienkunde \\ des Mittelalters und der frühen Neuzeit, \\ Austria, znorovszkyandrea@gmail.com
}

\begin{abstract}
This paper concentrates on the dissemination of Marian apocryphal imagery in Western Europe in relation to various textual sources used in devotional and liturgical contexts. It aims at presenting the geographic distribution, the confluence zones, and the density of Marian Apocryphal iconography with the purpose of establishing areas subject to individual case studies. Also, it highlights local developments and the incorporation of several iconographic themes into the apocryphal material.
\end{abstract}

Keywords: Middle Ages; Virgin Mary; Marian Iconography; liturgy; hagiographic collections; dissemination. 


\title{
The Apocryphal Geography of Virgin Mary in Hagiographic Collections: Dissemination and Liturgy
}

\author{
Andrea-Bianka Znorovszky \\ Austrian Academy of Sciences, Universität Salzburg, Institut für \\ Realienkunde des Mittelalters und der frühen Neuzeit, Austria
}

Despite the abundant literature on Marian iconography, which sets the Virgin's representations in theological, cultural, or art historical contexts, research seems to have treated sporadically ${ }^{1}$ only a particular group of representations, namely Marian Apocrypha. ${ }^{2}$ This essay

\footnotetext{
${ }^{1}$ See for instance, Josef Diaz, Suzanne Stratton-Pruitt, Painting the Divine. Images of Mary in the New World (Albuquerque: Fresco Fine Art Publishing, 2014). Lasse Hodne, The Virginity of the Virgin: a Study in Marian Iconography (Rome: Scienze e Lettere, 2012). Lois Swan Jones, Preston Jones, et al., Madonna and Child. The Virgin Mary in Art, Renaissance to Reformation (Dallas: Swan Jones Productions, 2008). Jacqueline Lafontaine-Dosogne, Iconographie de l'enfance de la vierge dans l'Empire Byzantin et en Occident, vol. I (Brussels: Beaux Arts, 1964). Eadem, Iconographie de l'enfance de la vierge dans l'Empire Byzantin et en Occident, vol. II (Brussels: Palais des Académies, 1965). David R. Cartlidge, J. Keith Elliott, Art and the Christian Apocrypha (London and New York: Routledge, 2001). Daniel Russo, "Les représentations mariales dans l'art d'Occident. Essai sur la formation d'une tradition iconographique," in Marie: le culte de la Vierge dans la société médiévale, ed. Dominique Iogna-Prat (Paris: Beauchesne, 1996), 175-291.

2 For research on Apocrypha, the current state of debate, and on the difficulty to distinguish hagiography from Apocrypha, see, for instance, Éric Junod, "Apocryphes $\mathrm{du}$ Nouveau Testament: une appellation erronée et une collection artificielle. Discussion de la nouvelle définition proposé par W. Schneemelcher," Apocrypha 3 (1992): 17-46; idem, "Apocryphes du Nouveau Testament ou apocryphes chrétiens anciens? Remarques sur la désignation d'un corpus et indications bibliographiques sur instruments de travail recents," Études Théologiques et Religieuses, 58/3 (1983): 409-421; Stephen. J. Shoemaker, "Between Scripture and Tradition: The Marian Apocrypha of Early Christianity," in The Reception and Interpretation of the Bible in Late Antiquity. Proceedings of the Montréal Colloquium in Honour of Charles Kannengiesser, 11-13 October 2006, eds. L. Ditommaso- L. Turcescu ( Leiden and Boston: Brill, 2008), 491-510, particularly 491- 496. Els Rose, Ritual Memory: The Apocryphal Acts and Liturgical Commemoration in the
} 
concentrates on the dissemination of Marian apocryphal imagery in Western and Central Europe in relation to various textual sources used in devotional and liturgical contexts. It presents the geographical distribution, the density, and the existent patterns of Marian Apocryphal iconography. ${ }^{3}$ The purpose is to establish areas or topics that are subject to particular case studies. Furthermore, it also highlights certain local developments and the incorporation of several iconographic themes into the apocryphal material.

This essay is structured in two parts, the first one concentrates on the variety of Marian Apocryphal visual representations, with emphasis on the Virgin's youth and on those episodes in which Mary's role seems to have increased (whereas that of the Child decreased ${ }^{4}$ ), while the second focuses on the liturgical contextualization and use of hagiographic collections, in relation to the collected material, as reflected by previous scholarship. This iconographic compilation numbers more than six hundred representations, including illuminations, frescoes, altarpieces, etc. The databases used for collecting these depictions already suggest certain key areas where they are more abundant, namely France, the Low Countries, Germany, Austria, Italy and, England, while Denmark, Hungary, the Czech Republic, Slovakia, and Romania/Transylvania represent the marginal areas of dissemination.

\section{Hagiographic collections}

The collected manuscript illuminations are found in hagiographic collections such as Vies de Saints, Legenda Aurea, Speculum Historiale,

Early Medieval West (c. 500-1215) (Leiden: Brill, 2009), see, particularly chapter 1, “The Apocryphal Acts and liturgical commemoration," 23-78.

3 The collection of visual material for Italy and the Germanic areas is still in progress. The following image databases have been consulted so far:

http://www.bnf.fr/fr/acc/x.accueil.html,http://www.enluminures.culture.fr/documen tation/enlumine/fr/,

http://mandragore.bnf.fr/jsp/rechercheExperte.jsp,http://www.fotomarburg.de/, http://tethys.imareal.sbg.ac.at/realonline, http:/ /www.huntington.org/, https://www.bl.uk/. (All accessed: March 23, 2018).

4 Daniel Russo, "La sainte famille dans l'art Chrétien au moyen-âge. Étude iconographique," in Marie et la Sainte Famille. Les récits apocryphes chrétiens, vol. II, eds. Charles Perrot-Enrico Norelli (Paris: Médiaspaul, 2006), 101-118. 
Speculum Humanae Salvationis, Vita Jesu Christi, Books of Hours, and many more. ${ }^{5}$

Although all these textual sources contain depictions of Mary's earlier life, based on the hagiographic sources one should note the possibility of classifying such visual representations into three groups with their own particularities.

\section{Speculum collections}

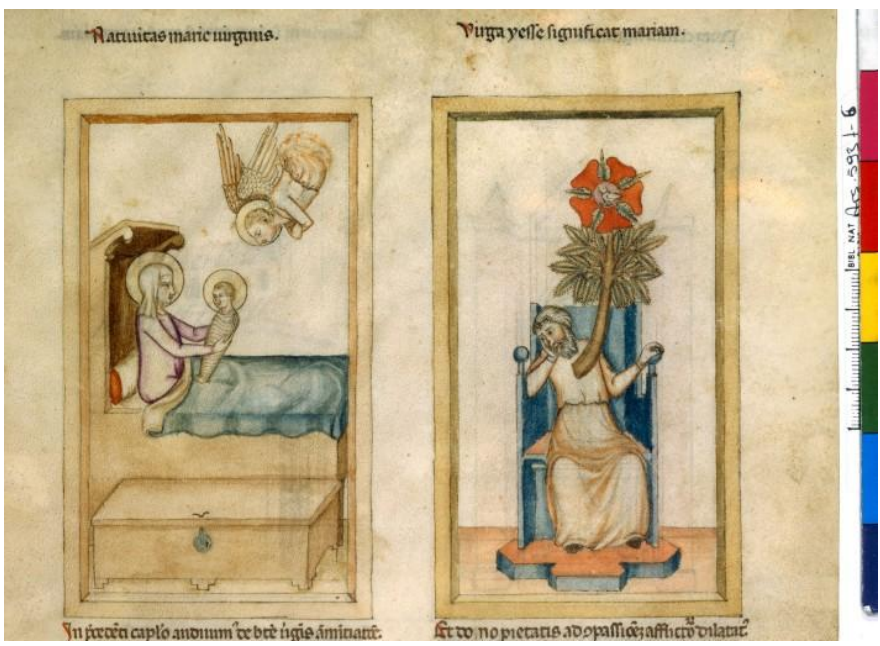

Fig. 1. Nativity of the Virgin, Paris, National Library of France, Ms. Arsenal 593, Speculum humanae salvationis, Bologna, fourteenth century, fol. 6.

(Last accessed: 23 March, 2018, http://mandragore.bnf.fr/jsp/rechercheExperte.jsp)

${ }^{5}$ As the research is still in an incipient phase, versions of the Gospel of Pseudo Matthew have not been consulted in order to identify whether there are any miniatures which could advance the investigation. There are, for instance, 200 manuscripts of the Gospel of Pseudo Matthew, of which 70 date prior to the thirteenth century, and around 140 manuscripts on the Birth of Mary, dating again prior to the thirteenth century, see Rita Beyers, "La réception médiévale du matériel apocryphe concernant la naissance et la jeunesse de Marie: Le Speculum Historiale de Vincent de Beauvais et la Legenda Aurea de Jaques de Voragine", in Marie dans les récits apocryphes Chrétiens, eds. É. Cothenet- J. Roten (Paris: Médiaspaul, 2004), 183. 


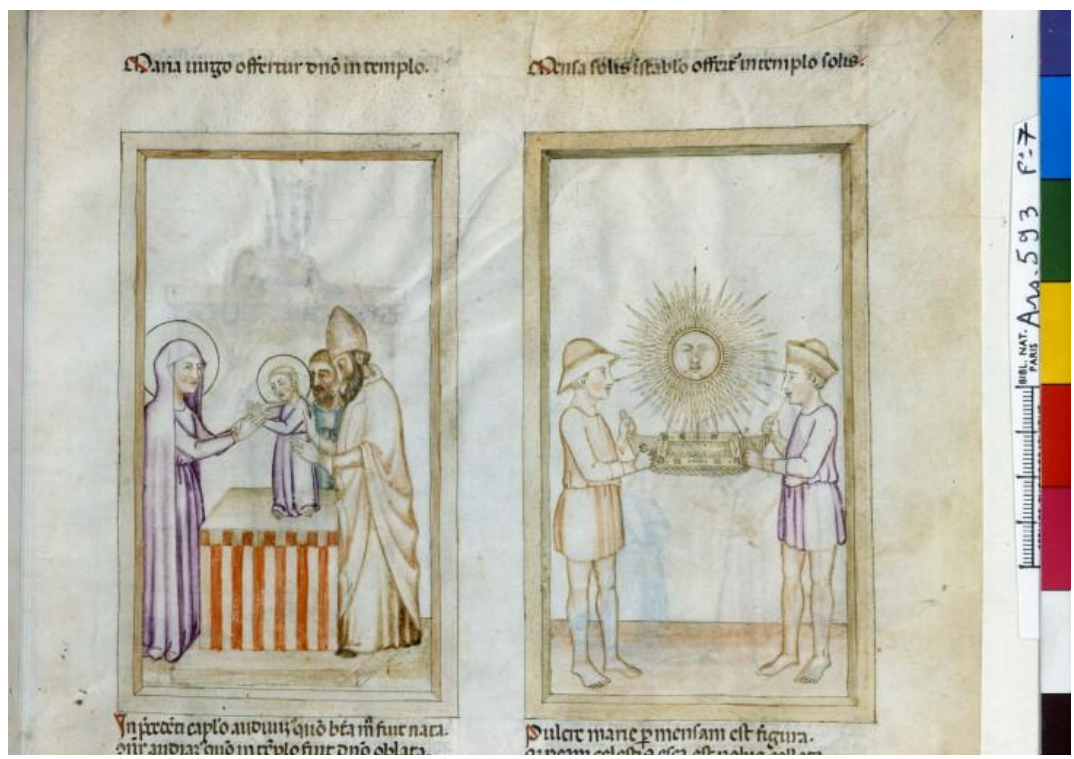

Fig. 2. Presentation at the Temple, Paris, National Library of France, Ms. Arsenal 593, Speculum humanae salvationis, Bologna, fourteenth century, fol. 7. (Last accessed: 23 March, 2018, http://mandragore.bnf.fr/jsp/rechercheExperte.jsp)

Most of the collected representations ${ }^{6}$ are found in versions of the Speculum Humanae Salvationis and Speculum Historiale, they are either from France, including French speaking territories, Germanic areas and to a lesser extent Italy. Generally, the representations belonging to versions of the Speculum Humanae Salvationis are typological representations in which episodes of Mary's life are paired with some of the Old Testament as it follows: Nativity of Mary - Tree of Jesse, Betrothal of Mary and Joseph - Betrothal of Sarah and Tobias, or more allegorical ones such as the Presentation at the Temple - Fishermen/Representation of a Temple; Mary defeating the Devil - Judith beheading Holofernes, as is found in a fourteenth-

${ }^{6}$ In an initial phase, the compilation suggested a density of visual representations specific for versions of the Legenda Aurea as indicated in Andrea-Bianka Znorovszky, "Beyond the Borders of Canonicity? The Virgin Mary, Apocryphal Iconography, and Hagiographic Collections in Fourteenth-Sixteenth-Century France," in Graniţe, teritorii, comunităti [Borders, Territories, Communities], eds. Cristina Bogdan, Silvia Marin Barutcieff (Bucharest: Editura Universităţii din Bucureşti, 2018 accepted for publication). 
century Italian manuscript (fig. 1 and 2)..$^{7}$ As well, this pattern is found in other French versions of the Speculum Humanae Salvationis. ${ }^{8}$

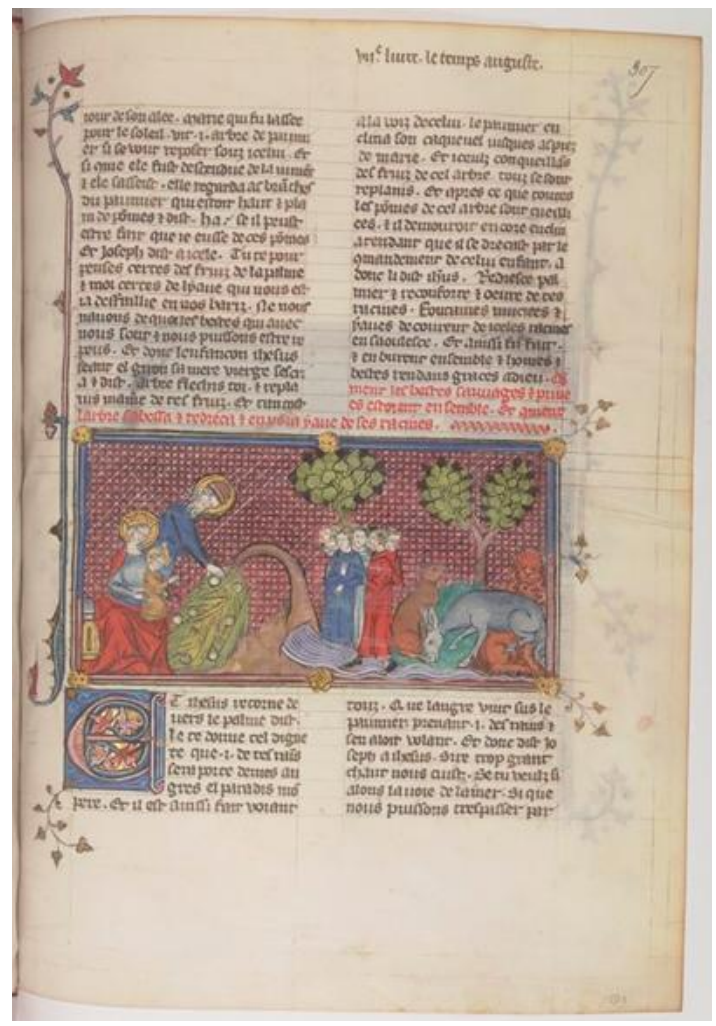

Fig. 3. Miracle of the Palm Tree, Paris, National Library of France, Ms. Français 316, Speculum historiale, Paris, 1333, fol. 307v.

(Last accessed: 23 March, 2018, http://mandragore.bnf.fr/jsp/rechercheExperte.jsp)

7 Paris, National Library of France, Ms. Arsenal 593, Speculum bumanae salvationis, Bologna, fourteenth century, fols. 5, 6, 7, 8, and 24 (Last accessed: 23 March, 2018, http://mandragore.bnf.fr/jsp/rechercheExperte.jsp).

8 Paris, National Library of France, Ms. Français 512, Speculum bumanae salvationis, Basel, fifteenth century, fol. 4; Paris, National Library of France, Ms. Latin 511, Speculum bumanae salvationis, Alsace, 1370-80, fol. 5v; Paris, National Library of France, Ms. Latin 512, Speculum humanae salvationis, Basel, fifteenth century, fol. 6v; Paris, National Library of France, Ms. Latin 9585, Speculum humanae salvationis, fifteenth century, fol. 9. All last accessed: 23 March, 2018, http://mandragore.bnf.fr/jsp/rechercheExperte.jsp). 
What is interesting with regard to a French manuscript is that the Marian episodes are entwined with Marian miracles in a structure reduced to miracle-life-miracle episodes. What one should note, in this manuscript, is the frequency of miracles, while the episodes of Mary's life resume to the Nativity, and the Presentation at the Temple, and the Flight into Egypt. The Apocryphal elements refer to Mary's birth, entrance into the temple, and, with regard to the Flight into Egypt, the miracle of the palm tree or the fall of the idols (fig. 3).9 This segmentation in representing Marian episodes is found also in a French manuscript of the Legenda Aurea ${ }^{10}$ which concentrates on the Nativity of Mary and on the Meeting at the Golden Gate, in a diachronic way, having the Nativity situated on folio 200v while other episodes follow on folio 290.

What should be noted in the above detailed cases, regardless of the area, is the typological reference to The Tree of Jesse and the concentration on three to four episodes: Nativity, Presentation at the Temple, Betrothal, and Flight into Egypt, all which coincide with some of the Marian liturgical feasts: Nativity, Presentation at the Temple and/or Conception of the Virgin.

\section{Meditationes Vitae Jesu Christi and/or Lives of Mary and Christ}

The second group offering a detailed representation of Mary's life refers to hagiographic collections such as the Lives of the Virgin and Jesus Christ, Liber de Ortu B. Mariae et Infantia Salvatoris, Meditationes Vitae Jesu Christi by John of Caulibus, and/or Vita Jesus Christi by Ludolph of Saxony. The material gathered so far shows a concentration of these collections particularly in Italy as indicated by thirteenth-to-fourteenth-

9 Paris, National Library of France, Ms. Français 316, Speculum bistoriale, Paris, 1333, fols. 291, 306v, 307, 307v (All last accessed: 23 March, 2018, http://mandragore.bnf.fr/jsp/rechercheExperte.jsp).

10 Paris, National Library of France, Ms. Français 242, Legenda Aurea, Paris, fifteenth century, fols. 200v and 290. For other versions of the Legenda Aurea, see The Nativity of Mary, Paris, National Library of France, Ms. Français 241, Legenda Aurea, 1348, Paris, fol. 236v. Paris, National Library of France Ms. Français, 245, Legenda Aurea, Paris, 1480- 1490, fol. 85. The Betrothal, Paris, National Library of France, see Ms. Français 244, Legenda Aurea, Paris, 1480-1490, fol. 107. The Flight into Egypt, see Paris, National Library of France, Ms. Français 244, Legenda Aurea, Paris, 1480-1490, fol. 27 bisv. (All last accessed: 23 March, 2018, http://mandragore.bnf.fr/jsp/rechercheExperte.jsp). 
century hagiographic collections. ${ }^{11}$ In an Italian manuscript ${ }^{12}$ episodes of Mary's life are interpolated with that of Christ. When referring to the Flight into Egypt, for instance, one can note that the Christ Child is much more active and increased in size in contrast to more condensed representations that are found in the Speculum Humanae Salvationis/Historiale. As well, this imagery implies closeness to the text.

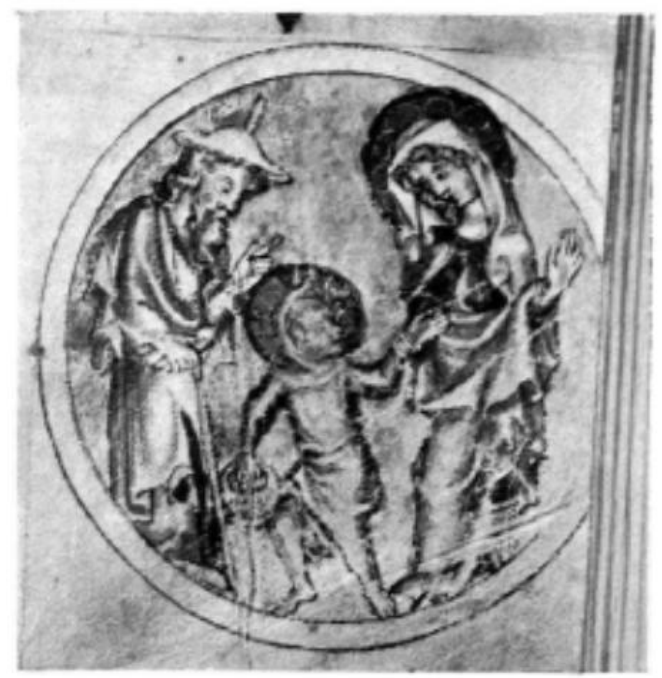

Fig. 4. Christ Child's life (episode), Ms. Gen. 8, folio 29, 1330, Austria. Municipal Library, Schaffhausen, Austria. Reproduced in Elisabeth LandoltWegener, Zum Motiv der "Infantia Christi" in Zeitschrift für schweizerische Archäologie und Kunstgeschichte 21 (1961): 171.

The Lives of the Virgin and Jesus Christ, Meditationes Vitae Jesu Christi, Liber de Ortu B. Mariae et Infantia Salvatoris suggest the complexity and circulation of the visual and apocryphal material which has been

\footnotetext{
11 Paris, National Library of France, Ms. 9561, The Lives of Mary and Christ, Italy, Naples, 1350. Paris, National Library of France, Ms. Latin 2688, Liber de ortu b. mariae et infantia salvatoris, Italy, Rome, thirteenth century; Paris, National Library of France, Ms. Italien 115, Meditationes Vitae Christi, Italy, Siena, 1330-1340. (All last accessed: 23 March, 2018, http://mandragore.bnf.fr/jsp/rechercheExperte.jsp).

12 Paris, National Library of France, Ms. Latin 2688, Liber de ortu b. mariae et infantia salvatoris, Italy, Rome, thirteenth century. (All last accessed: 23 March, 2018, http://mandragore.bnf.fr/jsp/rechercheExperte.jsp).
} 
incorporated in various degrees into religious texts. One should also note the multiplication of episodes in connection to this particular group. These types are not restricted to the Italian or French areas, but are also to be found in Germanic areas (fig. 4) as indicated by certain miniatures that concentrate on Christ Child's life. ${ }^{13}$

\section{Books of Hours}

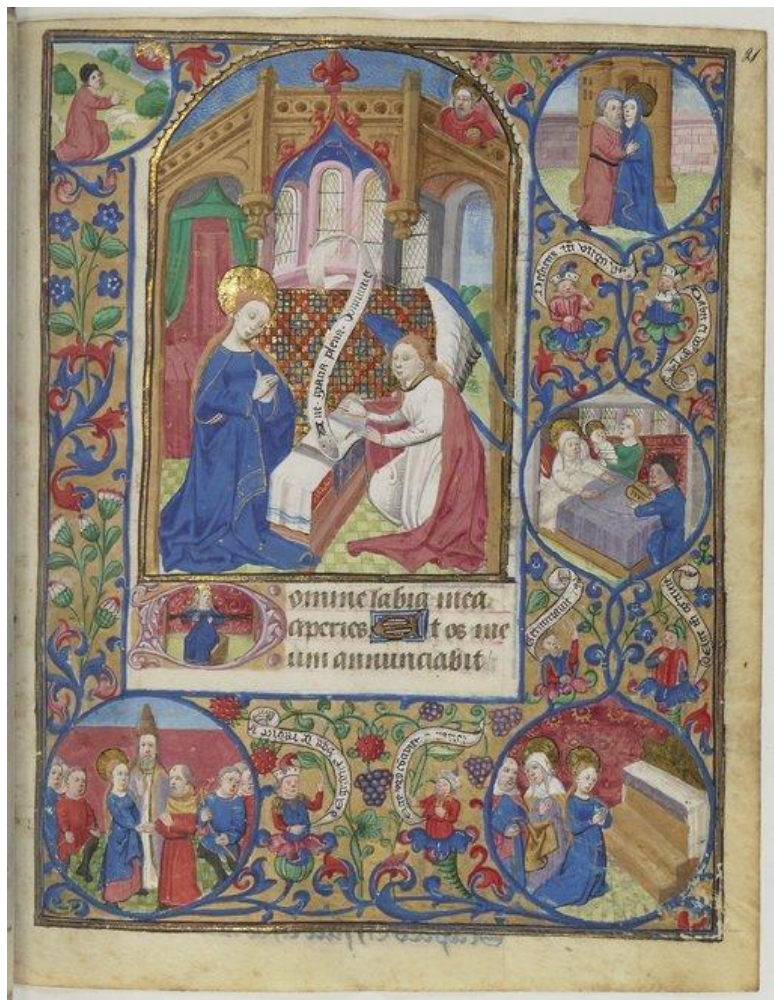

Fig. 5. The Annunciation, Paris, National Library of France, Ms. 1175, Book of Hours, use of Paris, France, fifteenth century, fol. 21.

(Last accessed: 23 March, 2018, http:/ /www.enluminures.culture.fr/documentation/enlumine/fr/)

\footnotetext{
13 Schaffhausen (Switzerland) Stadtbibliothek, Ms. Gen. 8, Austrian, c. 1330, fol. 29, reproduced in Elisabeth Landolt-Wegener, zum Motiv der "Infantia Christi," Zeitschrift für schweizerische Archäologie und Kunstgeschichte 21 (1961): 171.
} 
A considerable number of French miniatures, of apocryphal nature, are found in fourteenth-to-sixteenth-century Books of Hours (fig. 5). Some of these seem to have combined the display and the visual material of the previous two groups, Speculum and Meditationes collections, by depicting a central episode, the Annunciation, larger in size which is, then, surrounded by other smaller ones, those are: Meeting at the Golden Gate, Nativity of Mary, Presentation at the Temple, Betrothal as found in a fifteenthcentury French Book of Hours. ${ }^{14}$ (fig. 6). Furthermore, this group comes with other developments of the iconographic material concentrating on activities of Mary such as Weaving in the Temple, in her house, ${ }^{15}$ in an enclosed space, ${ }^{16}$ in an enclosed garden - bortus conclusus, ${ }^{17}$ or in a canopy. ${ }^{18}$ In the case of the hortus conclusus one observes that this space is now dedicated for various daily activities of Mary. What one should ask is whether details as mentioned above are to be considered Apocryphal developments or insertions, or whether they are not.

One such activity consists of Mary teaching the Christ Child to read. This pattern brings into discussion the use of the Apocryphal material as textual sources suggest that Christ had been brought by

14 Paris, National Library of France, Ms. 1175, Book of Hours (use of Paris), France, fifteenth century, fol. 21. ((Last accessed: 23 March, 2018, http://www.enluminures.culture.fr/documentation/enlumine/fr/).

15 See, for instance, Paris, National Library of France, Ms. NAL 3229, Books of Hours (use of Rome), France, Avignon, 1440-1450, fol. 71v. (Last accessed: 23 March, 2018, http://www.enluminures.culture.fr/documentation/enlumine/fr/).

16 Paris, National Library of France, Ms. Latin 1176, Book of Hours (use of Paris), 1450, fol. 180; Paris, Mazarine Library, Ms. Faralicq 07, Book of Hours (use of Rome), fifteenth century, fol. 24; Paris, National Library of France, Ms. Français 190, Meditationes Vitae Christi, 1483, fol. 144. (All last accessed: 23 March, 2018, http://www.enluminures.culture.fr/documentation/enlumine/fr/).

17 Paris, National Library of France, Ms. Latin 1183, Book of Hours and Prayers, 14601465, fol. 80; Besançon, France, Municipal Library, Ms. 0151, Book of Hours (use of Rome), fifteenth century, fol. 16v; Châlons-en- Champagne, France, Municipal Library, France Ms. 0334, Book of Hours (use of Lisieux), fifteenth century, fol. 30. (All last accessed: 23 March, 2018, http://www.enluminures.culture.fr/documentation/enlumine/fr/).

18 Paris, National Library of France, Ms. Latin 1161, Book of Hours of Jeanne Bessonnelle, 1415-1417, fol. 130v; Paris, National Library of France, Ms. Latin 1161, Book of Hours of Jeanne Bessonnelle, 1415-1417, fol. 130r; Amiens, France, Municipal Library, Ms. 0200, Book of Hours (use of Paris), 1415-1417, fol. 21; Besançon, France, Municipal Library, Ms. 0147, Book of Hours, 1440-1450, fol. 44v. (All last accessed: 23 March, 2018, http://www.enluminures.culture.fr/documentation/enlumine/fr/). 
Mary to learn, as is visualized in a Book of Hours from $1510 .{ }^{19}$ The Gospel of Pseudo-Matthew mentions that:

A second time the master Zachyas, doctor of the law, said to Joseph and Mary, 'Give me the boy, and I shall hand him over to Master Levi, who shall teach him his letters and instruct him.' Then Joseph and Mary, soothing Jesus, took him to school, that he might be taught his letters by old Levi. And as soon as he went in he held his tongue. ${ }^{20}$

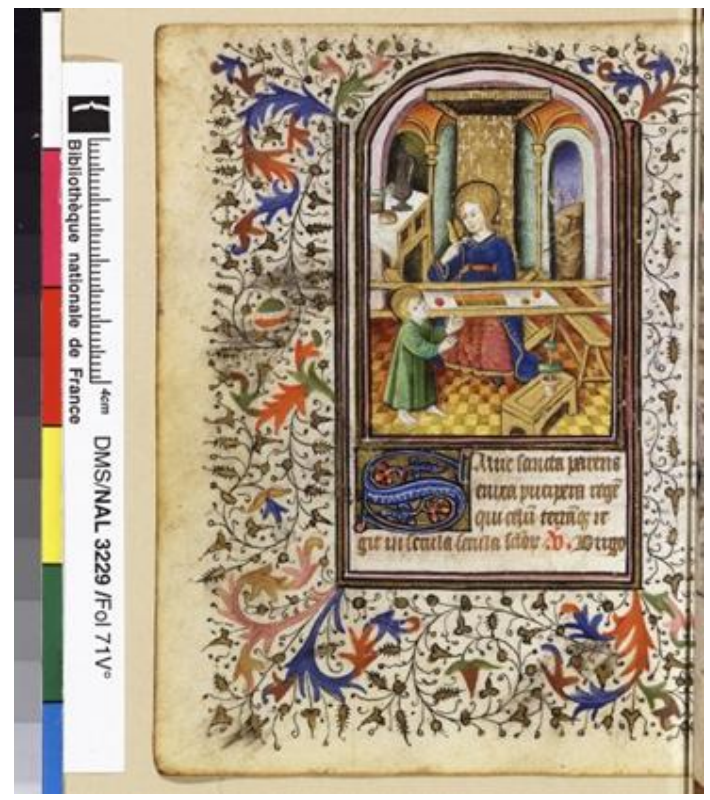

Fig. 6. Mary weaving with Christ Child, Paris, National Library of France, Ms. NAL 3229, Books of Hours, use of Rome, France, Avignon 1440-1450, fol. 71v.

(Last accessed: 23 March, 2018,

http://www.enluminures.culture.fr/documentation/enlumine/fr/).

19 Tours, France, Municipal Library, France, Ms. 2104, Books of Hours (use of Rome), France, Bourbon, 1510, fol. 124. This particular miniature is placed at the commencement of a prayer dedicated to the Virgin. (Last accessed: 23 March, 2018, http:/ /www.enluminures.culture.fr/documentation/enlumine/fr/).

20 J.K. Elliott, A Synopsis of the Apocryphal Nativity and Infancy Narratives (Leiden: Brill, 2006), 175. 


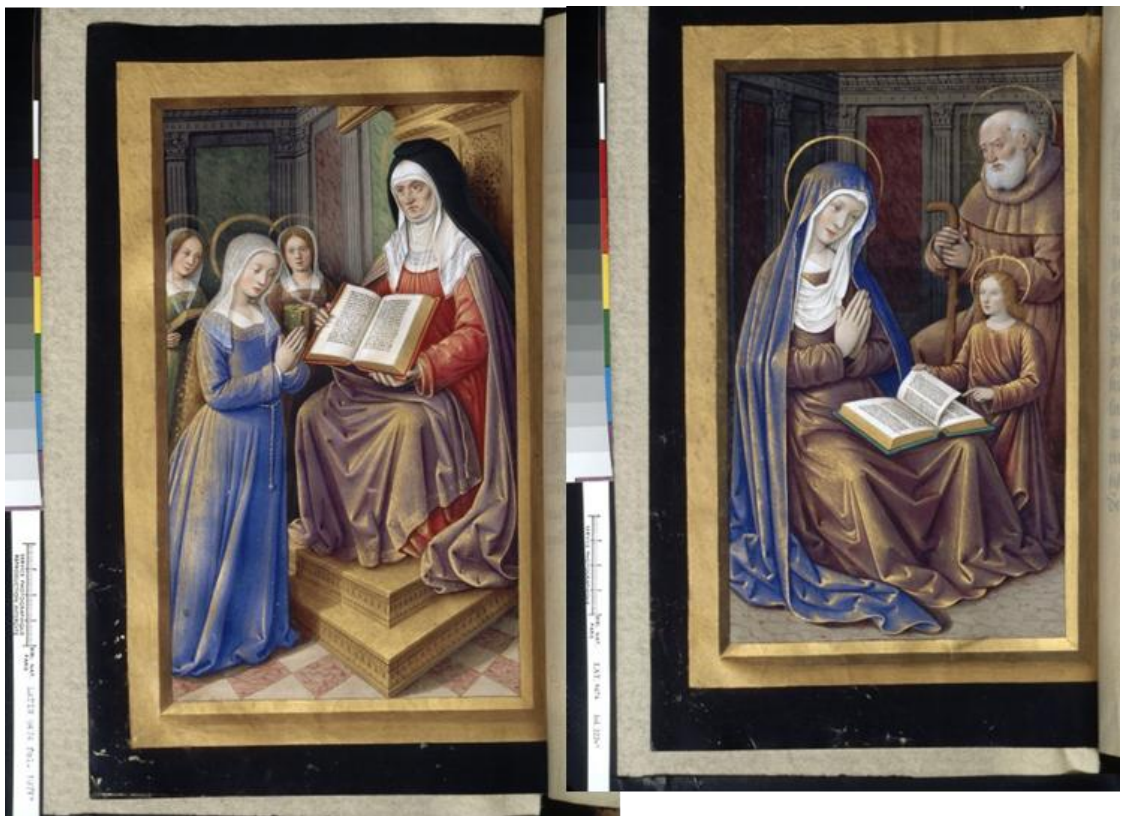

Figs. 7, 8. Mary learning to Read helped by Saint Anne, Mary teaching Christ Child to Read, Paris, National Library of France, Ms. Latin 9474, Book of Hours use of Rome/ Hours of Anne of Brittany, France, Tours, 1503-1508, fols. 197v and $222 \mathrm{v}$.

(Last accessed: 23 March, 2018, http://mandragore.bnf.fr/jsp/rechercheExperte.jsp)

Is this depiction a development of an apocryphal source if one bears in mind representations that concentrate on Saint Anne teaching Mary to read and, then, Mary teaching the Christ Child, as in a sixteenth-century manuscript?21 (fig. 7 and 8). Can one consider representations such as the Writing Christ Child an Apocryphal development? Is it possible that Mary had taken over the function of the Apocryphal teacher who previously taught the Christ Child? Apparently, the answer is positive as

21 Paris, National Library of France, Ms. Latin 9474, Book of Hours (use of Rome)/ Hours of Anne of Brittany, France, Tours, 1503-1508, fols. 197v and 222v. (Last accessed: 23 March, 2018, http://www.enluminures.culture.fr/documentation/enlumine/fr/). 
indicated by the above mentioned manuscript and other similar ones, ${ }^{22}$ which depict the Christ Child in the proximity of Mary who carefully instructs him.

Another domestic activity of Mary consists of her nursing the child or working. ${ }^{23}$ This connects the depiction to the Meditationes Vitae Christi, of John of Caulibus, who presents Mary as a woman performing working activities. ${ }^{24}$

The consulted material indicates that representations such as Mary weaving were included into manuscripts used for devotional or liturgical purposes. One concentrates on Mary preparing the Christ Child's bath, ${ }^{25}$ and is included in a prayer book of Pope Clement VII, while another one was used for liturgical purposes. The liturgical context brings into discussion the connection and the contribution of liturgy in the development and incorporation of Marian apocryphal textual sources both into hagiographic collections and into the liturgical text as well, not to speak of its influence on the dissemination of Marian iconography.

\section{Church space}

In the following, the paper concentrates on Germanic/Austrian material, that is, in apocryphal visual and textual material circulated from hagiographic collections to church space, either as frescoes or panel paintings. This is in order to emphasize the transition from hagiographic visual representations to frescoes and/or panel paintings. The collected material, in this specific area, indicates a concentration on three to four particular episodes, namely the Nativity, Presentation at the Temple, Betrothal, Flight into Egypt, which coincide, again, with the

22 See, for instance, The Hague, The National Library of the Netherlands, Ms. The Hague, KB, 74 G37, Books of Hours (use of Paris), France, Paris, 1455, fol. 12r. (Last accessed: 23 March, 2018, http://mandragore.bnf.fr/jsp/rechercheExperte.jsp).

23 See for instance, Amiens, France, Municipal Library, Ms. 0201, Book of Hours (use of Amiens), fifteenth-sixteenth century, fol. 143; Paris, National Library of France, Ms. 1191, Book of Hours of Louis de Roncherolles, 1495-1500, fol. 7 (All last accessed: 23 March, 2018, http://www.enluminures.culture.fr/documentation/enlumine/fr/).

${ }^{24}$ Daniel Russo, La sainte famille, 117.

25 Avignon, France, Municipal Library, Ms. 6733, Book of prayers, 1378-1383, fol. 68; Municipal Library, Tours, France, Ms. 2104, Books of Hours (use of Rome), France, Bourbon, 1510, fol. 124. (All last accessed: 23 March, 2018, http://www.enluminures.culture.fr/documentation/enlumine/fr/). 
episodes highlighted by the Speculum or the Legenda Aurea. Some of these representations are found in Salzburg, Tirol, Vienna, and Klosterneuburg in Austria, or Freising and Hamburg in Germany. Generally, they are fifteenth-to-sixteenth-century winged altarpieces or panel paintings. In the following example, I offer one short case study in order to emphasize various incorporations into the visual material.

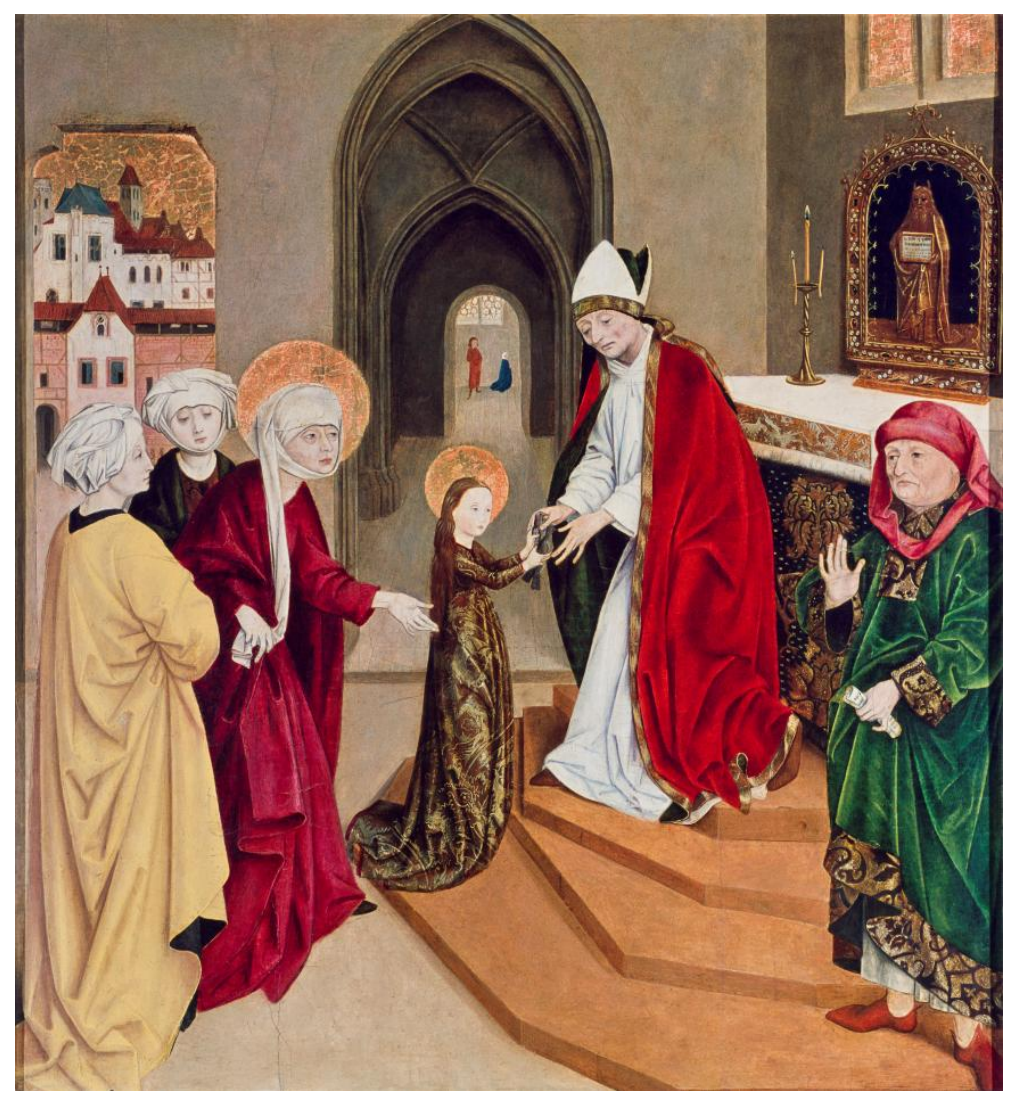

Fig. 9. Presentation at the Temple, Vienna, Museum of the Scots' monastery, panel painting of a winged altarpiece, Master of the Scots' altarpiece, Vienna, 1470s.

(Last accessed: 23 March, 2018, http://tethys.imareal.sbg.ac.at/realonline/) 
In the Presentation at the Temple, Mary enters the holy space after leaving behind her family and being placed on the altar. ${ }^{26}$ Mary is depicted either walking the stairs to the temple, ${ }^{27}$ indicated by textual sources, as in a fifteenth-century altarpiece from Salzburg, or the stairs to the altar, as suggested by another fifteenth-to-sixteenth century altarpiece, ${ }^{28}$ where she is welcomed by a priest. It is precisely these details which point to the use and development of the apocryphal material and its incorporation such as indicated by the second altarpiece where Mary offers/hands-over two doves to a priest (fig. 9). Such details seem to be missing in the Protoevangelium of James which presents the episode of Mary's Presentation at the Temple as such:

When the child turned three, Joachim said, "We should call the undefiled daughters of the Hebrews and have each take a torch and set them up, blazing, that the child not turn back and her heart be taken captive away from the Temple of the Lord." They did this, until they had gone up to the Lord's Temple. And the priest of the Lord received her and gave her a kiss, blessing her and saying, "The Lord has made your name great among all generations. Through you will the Lord reveal his redemption to the sons of Israel at the end of time." He set her on the third step of the altar, and the Lord God cast his grace down upon her. She danced on her feet, and the entire house of Israel loved her. ${ }^{29}$

26 The iconographical pattern of the Presentation at the Temple concentrates on two details: Mary not turning back to look at her parents and her walking the fifteen steps, see Achilles Stubbe, La Madone dans L'Art (Brussels: Elsevier, 1958), 34. When speaking about the differences between text and image, I would also add the lack of Mary's visual representations as dancing. Accordingly, when entering the temple, the priest placed Mary on the third step of the altar and she danced while the Lord cast grace upon her.

${ }^{27}$ Herzogenburg (Lower Austria), Gallery of the Austin canon house, Presentation at the Temple, panel painting of a winged altarpiece, Salzburg, or Passau, c. 1500.

28 Vienna, Museum of the Scots' monastery, Presentation at the Temple, panel painting of a winged altarpiece, Vienna, 1470s.

${ }^{29}$ Bart D. Ehrman, Zlatko Pleše, The Aporryphal Gospels. Texts and Translations (Oxford: Oxford University Press, 2011), 44. 
While The Gospel of Pseudo-Matthew states the following:

After these things, when her nine months were completed, Anna brought forth a daughter and named her Mary. When Anna finished nursing her in her third year, Joachim and Anna his wife went up together to the Temple of the Lord. They offered sacrificial victims to the Lord and handed over their little girl Mary to the company of virgins, who continuously praised God, day and night. When she was placed before the Temple, she ascended the fifteen steps of the Temple so quickly that she did not look back at all or seek after her parents, as infants customarily do. When this happened everyone was struck with wonder, so that the priests of the Temple themselves were amazed. ${ }^{30}$

When comparing the second panel painting with the apocryphal textual sources, there are several developments and differences. For example, Mary is in the company of Saint Anne, her mother, and two women. As well, one should also highlight the presence of another man at the side of the altar which appears in other instances. ${ }^{31}$ This development does not belong only to altarpieces, as a fifteenth-century German Graduaß2 concentrates on Mary walking the stairs only in the company of Saints Anne and Joachim whereas at the altar no one awaits her except Christ on the altarpiece. Has Christ become a substitute for the priest? This is

\footnotetext{
30 Idem, The Apocryphal Gospels, 67.

31 St. Florian (Upper Austria), Austin canon house, Presentation at the Temple, panel of a winged altarpiece, Vienna, 1490-1500. Vienna, Austrian Gallery, IN 4863, The Virgin as temple virgin, panel of a winged altarpiece, Master of Mondsee, end of the fifteenth century. Vienna, Austrian Gallery, IN 4905, Presentation at the Temple, panel of a winged altarpiece, Master of Schloss Lichtenstein, 1440-1450 (All to be found at: http://tethys.imareal.sbg.ac.at/realonline/, last accessed: 23 March, 2018). A similar altar cloth to this one is found in a fourteenth-century Italian (Naples) manuscript on the Lives of the Virgin and Christ, Paris, National Library of France, Ms. Français 9561, fourteenth-century, Italy, Naples, folio 119.

32 Munich, Bayerische Staatsbibliothek, Ms. Clm. 23042, Gradual, Augsburg, 1494-1497, fol. 79v. (Last accessed: 23 March, 2018, http://tethys.imareal.sbg.ac.at/realonline/).
} 
also found in other fifteenth-century material from modern Slovenia ${ }^{33}$ or the Czech Republic. ${ }^{34}$ What is interesting about the Czech representation is the presence of an open book and that of the Virgin Mary and the Christ Child on the altarpiece, as if indicating to young Mary the significant role she has for humankind. Another remark concerning the above detailed images is the increase in the presence of Saint Anne next to the Virgin.

\section{Liturgy and hagiographic collections}

While previous scholarship on Marian iconography has traced developments from textual to visual sources, one should consider it essential to investigate the liturgical context, that is, those in which depictions of Mary were used, since they were far more significant to their evolution, popularity, and dissemination. These approaches therefore, build on a range of scholarship which has outlined the importance of sacred space to our understanding of religious cultures. In the following, the discussion brings several works that tackle the connection between liturgy and apocryphal literature as this is an aspect which still needs an extensive analysis already indicated by Els Rose's Ritual Memory. 35

Rita Beyers, when referring to the proliferation of the liturgical feast of the Assumption of Mary in the Latin West, also states the importance of creating reading material for this feast. ${ }^{36}$ In parallel to this, one should add, in the later Middle Ages, that one witnesses the proliferation of other Marian feasts, such as the Presentation at the Temple, meaning that besides the creation and the need of reading material, one can speak also about the need of visualizing that textual material.

33 Vrzdenec (Slovenia), filial church St. Kantianus, Presentation at the Temple, wall painting, last quarter of the fifteenth century (Last accessed: 23 March, 2018, http://tethys.imareal.sbg.ac.at/realonline/)..

34 Pruhonice (Czech Republic), Church of the Birth of Mary, Presentation at the Temple, panel of a winged altarpiece, Master of the Vejprnice altar, c, 1490 (Last accessed: 23 March, 2018, http://tethys.imareal.sbg.ac.at/realonline/).

35 Els Rose, Ritual Memory, 3. Rose mentions that the only research done on the connection between liturgical and Apocryphal sources is with regard to Saint Andrew.

36 Rita Beyers, "The Transmission of Marian Apocrypha in the Latin Middle Ages" in Aporrypha 23, ed. J.-D. Dubois (Turnhout: Brepols, 2012), 125. 
This phenomenon is related to the proliferation of Lives of Mary, which is seen in the sources consulted for the visual material subject of this paper. This proliferation emerged in the West around the twelfth century, one of the first of such lives being the Conception Nostre Dame, by Robert de Wace. ${ }^{37}$ Another such life, Vita Beatae Virginis Mariae et Salvatoris Rhythmica, dated to the first half of the thirteenth century should be situated in the context of Marian developments, as it was used as liturgical reading in monastic space combining the life of Mary and Jesus, albeit that Mary's is more developed. It is based on the Latin translation by Epiphanius the Monk, an eight-ninth century monk and priest at Kallistratos monastery in Constantinople, of Life of the Virgin, and perhaps as well the Pseudo Matthew. In the prologue and epilogue of the Vita Rhythmica the author, Werner the Swiss, attempts to explain the value of Apocrypha which are his main source, and he underlines the complementary character of it in connection to the Gospels that do not offer enough data on Mary or Jesus. ${ }^{38}$ What one should note in this particular case is the liturgical function and the use of Apocrypha in order to supplement details of Mary's life followed by the visualization of it.

Another aspect related to Apocrypha is their use in hagiographic collections. Accordingly, Jean of Mailly in his Abbreniatio included apocryphal sources on the birth and youth of the Virgin and later added other apocryphal details from the Pseudo Matthew such as the weaving of Mary. Such hagiographic collections were used by various audience as it follows: Mailly's audience were parish priests who did not have books; Bartholomew of Trente's Liber epilogorum was used for preaching and spiritual edification, with high emphasis on the liturgical feasts, a particular characteristic of the Dominicans' Marian devotion; while Vincent of Beauvais' Speculum was used by the Dominican confraternities, for teaching, for preaching, and Bible study. ${ }^{39}$

\footnotetext{
37 Eadem, 125 , note 36.

38 Simon C. Mimouni, "Les vies de la Vierge. État de la question," Apocrypha 5 (1994): 246.

${ }^{39}$ Beyers, La réception médiévale, 188, 200. See also Stephen. J. Shoemaker, Between Scripture and Tradition, 497-501. The Protevangelium manuscripts had a liturgical nature and were read for feasts such as Mary's Nativity. The Pseudo Gospel of Matthew adds a few traditions, among them The Holy Family's Flight into Egypt. The process of integrating Apocrypha takes place already in Late Antiquity/early Middle Ages when early apocryphal material
} 
On the other hand, although the above authors had a skeptical attitude towards Apocrypha, still they included such apocryphal details in their hagiographic collections. Accordingly, Jean of Mailly had a severe attitude towards Apocrypha which are considered the opposite of truth or the opposite of history, that is, Apocrypha versus historiae or Apocrypha versus autenticae scripturae. Whenever he inserts apocryphal details, he mentions this and emphasizes the need to show prudence with these sources. In Bartholomew of Trente's, Liber Epilogorum, apocryphal narrations are blended together with various other ones without any supplementary information, while Vincent of Beauvais offers a hierarchy that distinguishes between different groups of Apocrypha. He uses in his work Apocrypha that, according to his distinctions, are accessible for various audiences, but also warns his readers concerning the origin of the information. Jacobus de Voragine does not connect the notion of Apocrypha to canonicity, but to reliability. Still he maintained a prudent attitude, particularly to those sources that pertain to faith, as he borrows Vincent's category of Apocrypha that can be cited and indicates this origin by quotation marks. ${ }^{40}$

\section{Conclusions}

To sum up, I would like to highlight the followings:

1. The existence of three groups, Speculum Collections, Meditationes Vitae Jesu Christi and/ or Lives of Mary and Christ, and Books of Hours for the miniatures of Apocryphal influence and/or origin. While the first and the third groups seem to be less connected to the text, the second one seems to offer literal representations of it.

2. The enclosed space becomes a pretext for representations of the Virgin's daily life. Furthermore, images such as the Virgin teaching

was revised and adopted for a liturgical setting, read for spiritual instruction, thus, becoming part of Church Tradition.

40 Giovanni Paolo Maggioni, "La littérature apocryphe dans La Légende Dorée et dans ses sources immédiates. Interprétation d'une chaîne de transmission culturelle," in Apocrypha 19, ed. J.-D. Dubois (Turnhout: Brepols, 2008), 146-181. See, particularly, 171-173. 
Christ Child might be connected to the gradual increase of the cult of Saint Anne.

3. The density of the collected visual material seems to reflect and to concentrate on Marian liturgical feasts, those are: the Nativity or Presentation at the Temple.

4. One should note the liturgical use of these hagiographic collections and the incorporation of the Apocryphal material in these collections. Furthermore, one should also note the influence of the texts on the images which represent the narrative according to these apocryphal sources. All this brings into discussion the need of further research on the insertion of apocryphal material into Marian liturgical sources and following images.

\section{References}

\section{Primary sources}

\section{Manuscripts}

Amiens, France, Municipal Library, Ms. 0200, Book of Hours (use of Paris), 1415-1417, fol. 21.

Amiens, France, Municipal Library, Ms. 0201, Book of Hours (use of Amiens), fifteenth-sixteenth century, fol. 143.

Avignon, France, Municipal Library, Ms. 6733, Book of prayers, 13781383, fol. 68.

Besançon, France, Municipal Library, Ms. 0147, Book of Hours, 14401450, fol. 44v.

Besançon, France, Municipal Library, Ms. 0151, Book of Hours (use of Rome), fifteenth century, fol. 16v.

Châlons-en-Champagne, France, Municipal Library, France Ms. 0334, Book of Hours (use of Lisieux), fifteenth century, fol. 30.

Hague, The National Library of the Netherlands, Ms. The Hague, KB, 74 G37, Books of Hours (use of Paris), France, Paris, 1455, fol. 12r.

Munich, Bayerische Staatsbibliothek, Ms. Clm. 23042, Gradual, Augsburg, 1494-1497, fol. 79v.

Paris, Mazarine Library, Ms. Faralicq 07, Book of Hours (use of Rome), fifteenth century, fol. 24.

Paris, National Library of France Ms. Français, 245, Legenda Aurea, Paris, 1480- 1490, fol. 85. 
Paris, National Library of France, Ms. 1175, Book of Hours (use of Paris), France, fifteenth century, fol. 21.

Paris, National Library of France, Ms. 1191, Book of Hours of Louis de Roncherolles, 1495-1500, fol. 7.

Paris, National Library of France, Ms. 9561, The Lives of Mary and Christ, Italy, Naples, 1350, fol. 119.

Paris, National Library of France, Ms. Arsenal 593, Speculum bumanae salvationis, Bologna, fourteenth century, fols. 5, 6, 7, 8, 24.

Paris, National Library of France, Ms. Français 190, Meditationes Vitae Christi, 1483, fol. 144.

Paris, National Library of France, Ms. Français 241, Legenda Aurea, 1348, Paris, fol. 236v.

Paris, National Library of France, Ms. Français 242, Legenda Aurea, Paris, fifteenth century, fols. 200v, 290.

Paris, National Library of France, Ms. Français 244, Legenda Aurea, Paris, 1480-1490, fol. 107.

Paris, National Library of France, Ms. Français 244, Legenda Aurea, Paris, 1480-1490, fol. 27 bisv.

Paris, National Library of France, Ms. Français 316, Speculum historiale, Paris, 1333, fols. 291, 306v, 307, 307v.

Paris, National Library of France, Ms. Français 512, Speculum bumanae salvationis, Basel, fifteenth century, fol. 4.

Paris, National Library of France, Ms. Italien 115, Meditationes Vitae Christi, Italy, Siena, 1330-1340.

Paris, National Library of France, Ms. Latin 1161, Book of Hours of Jeanne Bessonnelle, 1415-1417, fol. 130v-130r.

Paris, National Library of France, Ms. Latin 1176, Book of Hours (use of Paris), 1450, fol. 180.

Paris, National Library of France, Ms. Latin 1183, Book of Hours and Prayers, 1460-1465, fol. 80.

Paris, National Library of France, Ms. Latin 2688, Liber de ortu b. mariae et infantia salvatoris, Italy, Rome, thirteenth century.

Paris, National Library of France, Ms. Latin 511, Speculum bumanae salvationis, Alsace, 1370-1380, fol. 5v.

Paris, National Library of France, Ms. Latin 512, Speculum bumanae salvationis, Basel, fifteenth century, fol. $6 \mathrm{v}$. 
Paris, National Library of France, Ms. Latin 9474, Book of Hours (use of Rome)/ Hours of Anne of Brittany, France, Tours, 1503-1508, fols. $197 \mathrm{v}$ and $222 \mathrm{v}$.

Paris, National Library of France, Ms. Latin 9585, Speculum bumanae salvationis, fifteenth century, fol. 9.

Paris, National Library of France, Ms. NAL 3229, Books of Hours use of Rome, France, Avignon, 1440-1450, fol. 71v.

Schaffhausen (Switzerland), Stadtbibliothek, Ms. Gen. 8, Austrian, c. 1330, fol. 29.

Tours, France, Municipal Library, Ms. 2104, Books of Hours (use of Rome), France, Bourbon, 1510, fol. 124.

\section{Panel paintings and frescoes}

Herzogenburg (Lower Austria), Gallery of the Austin Canon House, Presentation at the Temple, panel painting of a winged altarpiece, Salzburg, or Passau, c. 1500.

Pruhonice (Czech Republic), Church of the Birth of Mary, Presentation at the Temple, panel of a winged altarpiece, Master of the Vejprnice altar, c, 1490.

St. Florian (Upper Austria), Austin canon house, Presentation at the Temple, panel of a winged altarpiece, Vienna, 1490-1500.

Vienna, Austrian Gallery- IN 4863, The Virgin as temple virgin, panel of a winged altarpiece, Master of Mondsee, end of the fifteenth century.

Vienna, Austrian Gallery, IN 4905, Presentation at the Temple, panel of a winged altarpiece, Master of Schloss Lichtenstein, 1440-1450.

Vienna, Museum of the Scots' monastery, Presentation at the Temple, panel painting of a winged altarpiece, Master of the Scots' altarpiece, Vienna, 1470s.

Vrzdenec (Slovenia), filial church St. Kantianus, Presentation at the Temple, wall painting, last quarter of the fifteenth century.

\section{Secondary Literature}

Ehrman, Bart D., Zlatko Pleše. The Apocryphal Gospels. Texts and Translations. Oxford: Oxford University Press, 2011.

Beyers, Rita. "La réception médiévale du matériel apocryphe concernant la naissance et la jeunesse de Marie.” In Marie dans les 
récits apocryphes Chrétiens I, eds. Édouard Cothenet, Johann Roten, 179- 200. Paris: Médiaspaul, 2004.

"The Transmission of Marian Apocrypha in the Latin Middle Ages." In Apocrypha 23, ed. J.-D. Dubois, 117-140. Turnhout: Brepols, 2012.

Cartlidge, David R., J. Elliott, Keith. Art and the Christian Apocrypha. London and New York: Routledge, 2001.

Diaz, Josef, Suzanne Stratton-Pruitt. Painting the Divine. Images of Mary in the New World. Albuquerque: Fresco Fine Art Publishing, 2014.

Elliott, J.K. A Synopsis of the Apocryphal Nativity and Infancy Narratives. Leiden: Brill, 2006.

Hodne, Lasse. The Virginity of the Virgin. A Study in Marian Iconography. Rome: Scienze e Lettere, 2012.

Junod, Éric. “Apocryphes du Nouveau Testament ou apocryphes chrétiens anciens? Remarques sur la désignation d'un corpus et indications bibliographiques sur instruments de travail recents." Études Théologiques et Religieuses, 58/3 (1983): 409-421.

"Apocryphes du Nouveau Testament: une appellation erronée et une collection artificielle. Discussion de la nouvelle définition proposé par W. Schneemelcher.” Apocrypha 3 (1992): 1746.

Lafontaine-Dosogne, Jacqueline. Iconographie de l'enfance de la Vierge dans l'empire Byzantin et en Occident I. Brussels: Beaux Arts, 1964.

. Iconographie de l'enfance de la Vierge dans l'empire Byzantin et en Occident II. Brussels: Palais des Académies, 1965.

Maggioni, Giovanni Paolo. "La littérature apocryphe dans La Légende Dorée et dans ses sources immédiates. Interprétation d'une chaîne de transmission culturelle." In Apocrypha 19, ed. J.-D. Dubois, 146181. Turnhout: Brepols, 2008.

Mimouni, Simon C. "Les Vies de la Vierge. É tat de la question." In Apocrypha 5, eds. Pierre Geoltrain, Jean-Claude Picard, 211-248. Turnhout: Brepols, 1994.

Rose, Els. Ritual Memory, the Apocryphal Acts and Liturgical Commemoration in the Early Medieval West (c. 500-1215). Leiden: Brill, 2009.

Russo, Daniel. "La sainte famille dans l'art chrétien au moyen-âge. Étude iconographique. " In Marie et la sainte famille dans les récits apocryphes chrétiens II, eds. Charles Perrot, Enrico Norelli, 101-119. Paris: Médiaspaul, 2006. 
. "Les représentations mariales dans l'art d'Occident. Essai sur la formation d'une tradition iconographique." In Marie: la culte de la Vierge dans la société médiévale, eds. Dominique Iogna-Prat, Eric Palazzo, 175-291. Paris: Beauchesne, 1996.

Shoemaker, Stephen. J. "Between Scripture and Tradition: The Marian Apocrypha of Early Christianity." In The Reception and Interpretation of the Bible in Late Antiquity. Proceedings of the Montréal Colloquium in Honour of Charles Kannengiesser, 11-13 October 2006, eds. L. Ditommaso, L. Turcescu, 491-510. Leiden and Boston: Brill, 2008.

Swan Jones Lois, Preston Jones et al., Madonna and Child. The Virgin Mary in Art, Renaissance to Reformation. Dallas: Swan Jones Productions, 2008.

Znorovszky, Andrea-Bianka. "Beyond the Borders of Canonicity? The Virgin Mary, Apocryphal Iconography, and Hagiographic Collections in FourteenthSixteenth-Century France." In Graniţe, teritorii, comunități [Borders, Territories, Communities] eds. Cristina Bogdan, Silvia Marin Barutcieff, Bucharest: Editura Universităţii din Bucureşti, 2018 (accepted for publication).

\section{List of illustrations}

Fig.1: Nativity of the Virgin, Paris, National Library of France, Ms. Arsenal 593, Speculum bumanae salvationis, Bologna, fourteenth century, fol. 6.

Fig. 2: Presentation at the Temple, Paris, National Library of France, Ms. Arsenal 593, Speculum bumanae salvationis, Bologna, fourteenth century, fol. 7.

Fig. 3: Miracle of the Palm Tree, Paris, National Library of France, Ms. Français 316, Speculum historiale, Paris, 1333, fol. 307v.

Fig. 4: Christ Child's life (episode), Ms. Gen. 8, folio 29, 1330, Austria. Municipal Library, Schaffhausen, Austria. (reproduced in Elisabeth Landolt-Wegener, Zum Motiv der "Infantia Christi" in Zeitschrift für schweizerische Archäologie und Kunstgeschichte 21 (1961): 164-172.

Fig. 5: The Annunciation, Paris, National Library of France, Ms. 1175, Book of Hours, use of Paris, France, fifteenth century, fol. 21.

Fig. 6: Mary weaving with Christ Child, Paris, National Library of France, Ms. NAL 3229, Books of Hours, use of Rome, France, Avignon 14401450 , fol. $71 \mathrm{v}$. 
Fig. 7: Mary learning to Read helped by Saint Anne, Mary teaching Christ Child to Read, Paris, National Library of France, Ms. Latin 9474, Book of Hours use of Rome/ Hours of Anne of Brittany, France, Tours, 15031508 , fol. $197 \mathrm{v}$.

Fig. 8: Mary learning to Read helped by Saint Anne, Mary teaching Christ Child to Read, Paris, National Library of France, Ms. Latin 9474, Book of Hours use of Rome/ Hours of Anne of Brittany, France, Tours, 15031508, fol. 222v.

Fig. 9: Presentation at the Temple, Vienna, Museum of the Scots' monastery, panel painting of a winged altarpiece, Master of the Scots' altarpiece, Vienna, 1470s. 